\title{
Profile
}

\section{The Metempiricism of Margins: Professor Anthony Așiwaju and the Circumference of Knowledge}

\author{
Toyin Falola \\ University Distinguished Teaching Professor \\ Jacob and Frances Sanger Mossiker Chair in the Humanities \\ The University of Texas at Austin \\ toyinfalola@austin.utexas.edu
}

Professor Anthony Așiwaju has written his memoir, Bridging Boundaries, to commemorate his $80^{\text {th }}$ birthday, thus giving us a treasure to behold, a legacy to cherish, and a history to keep. This is about his past, from humble beginnings to a remarkable career; about the educational system of Nigeria, in particular, the discipline of History; and about the crucial interconnectivity between ideas and practical policies. There is so much to be learned from this book-history, memory, wisdom-all the chemistry of ideas to navigate complicated journeys.

Let me begin this journey from Paris, and not from Imeko, the starting point in this engaging frontier of scholarship. It was in the elegant living room of Professor Olábiyí Yai, the then Ambassador of the Republic of Benin to UNESCO. As we enjoyed a peaceful pre- àmàlà drinking moment, we launched into a conversation that invoked Professor Așiwaju's name and experience. His Excellency, Ambassador Yai, made the remark that the Yoruba had always been diasporic, moving like a river, connecting multiple points, passing through valleys and plateaus, between mountains, across vegetations. This conversation came back to me as I composed this short piece. My mind also went back to the frontier towns of Imeko and Ifonyin, to the journeys I took from Igboho to Cotonou via the scenic route far away from the chaotic Lagos-Badagry road. Onwards to the Ewe, thereafter passing through the domains of the Akan, and at one time ending in Abidjan, all on roads-no bounds in space; no mental bounding lines; and seamless frontiers, one merging with the other, as the next unfolds. Professor Așiwaju does these diasporic 
trips as well-barefoot, bicycles, cars, and on airplanes-and, maybe, also in dreams. He sees the boundaries, then dissolves them, recreating them in a new world order, a world without boundaries.

I think Professor Așiwaju's life breaks the rules, creating a frame much larger than his beginnings. Contrary to the man-confining adage of "cut your coat according to your cloth/size," the autobiography of Professor Așiwaju has exemplified that the Supreme God cuts and designs coat without the delimitations or regard of one's size or cloth. If not, it would not have been possible for a child born without any medical attention and care on bare ground to rise into a nationally and internationally celebrated icon. Incontrovertibly, his destiny was predestined even before birth, what the Yoruba call àyànmọ, although the Odù Ifá code was never revealed to him. Thus, God designed the coat of his excellence above the odds of a humble and subaltern beginning of a poor child, now the prosperous Baba at 80 . How time flies!

Generous in his account, expansive in his details and meticulous in remembrance, the scope of his life is exposed to us in its minor canvas and major perimeter. Bridging Boundaries is a chronological account of the author's life from birth to date on the one hand, as well as the history of borderland studies in Nigeria and Africa, which is inseparable from his autobiography. The life of the author, Așiwaju, becomes the account of the așíwájú of the borderlands, the leader of the bold and courageous to discover the confines of space, like Ogún, the Yoruba god of iron, who forges new paths and abodes from the forest to the savanna for people to occupy.

Strikingly, the inseparability of the man's life from his career path appears to be synonymous with the bond between a snail and its shell: his origin and horizon live within the same shell. No doubt, his origin became the bedrock of his successful career. A scholar from cross-border parents with an upbringing in a borderland who specializes in borderland studies, which was initially focused on the Nigeria/Benin limitrophe states, then blossomed continentally and intercontinentally. Evident in his story is that a poor background neither limits nor determines the factor for the level of success one can attain; rather, it is a starting point, a background to project possibilities of whatever one can become unto, a launching pad into life's enduring legacy.

Once upon a time!

It all started on account of Așiwaju's birth to parents who were mainly peasant farmers with no goal of educational exposure for him because the normal way of life of that society was for children to aid their parents in farming and hunting. Consequently, a dream of a better method of farming was all peasant parents had to offer their children. His father was a native of Ketu, the famous Yoruba ancestral city in modern-day Republic of Benin. His mother was a native of Imeko, Ketu's twin sister on the Nigerian side of the border in 
Ogun State. However, he was born in Ekunkan, a village in Imeko where his parents settled in matrimony, thus being brought up with the values, traditions and systems of Imeko. These smaller confines had bigger cultural histories and extensive networks.

Ekunkan was a rural village in Imeko with limited exposure to modern facilities. The major occupation was peasant farming and hunting; and the social structure was based on communal living as is typical of an homogenous small village setting. The glorious ruralness is so much in evidence projected in the various narrations of his childhood, most especially the manner in which he was born in the absence of any midwife or nurse to assist his mother and no post-natal medical care after pushing him onto the bare ground with only mat and no bed. The village had no access to medical facilities. Medical conditions not considered life threatening in modern day were severe due to lack of appropriate care and could even result in an incurable debilitating condition or death. However, love, kinship, and communal living characterized the values with which he was groomed. Such was his early childhood until his father's decision to send him to school.

A modernist breakthrough was on the horizon. The life-changing opportunity of getting educated was the result of the migration of Așiwaju's parents from Ekunkan to Oyede, another village, but more developed than their previous settlement. Of course, land could not be packed alongside his luggage for the journey; thus, his father had no land of his own in the new settlement, which brought fear regarding the future of his farming as the hope of inheriting land became remote. More so, even though minimal, Western education was available at Oyede as opposed to Ekunkan, which was why the author's elder brother, who had been living with a relative in Oyede prior to their migration, had been enrolled in a school. However, the societal norm in Oyede was that only the first child was privileged to have education. Consequently, his father was seen as foolish and delusional by his peers when he decided to invest in the author's education as well, thereby having no helping hands on the farm he had just rented.

The quest for western education was the beginning of the author's exposure to a wider and heterogeneous world beyond the homogeneity of the small world into which he was born. A heterogeneous environment where mixing between people of diverse backgrounds, inevitably breeding different language contacts, came as a cultural shock for a boy from a culturally and linguistically homogeneous rural village. Thus, the school, St. Joseph's Catholic School, was a different world.

Emeritus professor, pioneer of a sub-discipline of comparative historical studies, started with difficulty in school, in academics and even in hygiene. Hygiene, because the young Așiwaju was a product of a rural environment 
so his skin was naturally never free from rashes due to farm activities, which resulted in his punishment for poor hygiene by the modern teachers. The numerous problems persisted so much that he considered withdrawing and embracing the initial plan of a farming future. However, the constant encouragement from his father, helped by his brother and his metamorphosing, kept him on the path that led to a successful life-long career.

As recounted by the author, his initial career goal was to become a teacher and retire as the principal of a secondary school because most of his mentors then fell in that category. Thus, he underwent formal trainings to become a professional teacher. He proceeded to St. Leo's Teacher Training College after his primary education and got conferred as a High Education Certificate (HEC) teacher in December 1959. Upon graduation, he practised the profession at different schools while concurrently working towards advancing in education. His admission into the University of Ibadan to study history was the launch of a new beginning for his life, a new perspective. The confines and edges of farming had become expanded to library and classroom spaces.

The aesthetics of this book, which makes it invaluably worthy of possession by any and everybody, is that in addition to its "autobiographic" purpose, it systematically incorporates historical details about important institutions such as the University of Ibadan, University of Lagos, and historical studies generally in Nigeria. It gives a detailed account of the status of the University of Ibadan as an institution formerly affiliated with London and along with the emergence, growth, and impacts of African History. He recounts the happy days of others as pioneers, as well as the growth of the discipline. The book is not just streamlined to the author's personal life history but also the history of everything that mattered in the course of his journey. It is thus an anthology of great historical moments.

The chronological account of the biography of borderland studies can be said to gradually connect three facets of maturity-starting with a national base confined to Nigeria, then extended into other borderland regions outside Nigeria but within Africa, and then maximally delving into the global realm. It is in this global realm that the focus shifts from the impacts of colonial administration on limitrophe locations to an emphasis on comparative borderland studies. The seed was however planted and watered in the soil of history studies at the University of Ibadan.

The high quality of the professional training and grooming here was the bedrock. The department, although focused on African History, encouraged versatility. The major courses were on Africa, its sub-regions of West, North, East and Southern Africa, etc. Elective courses from other fields like Arabic, political science, and French studies were allowed and encouraged, with significant relevance in the long run. Așiwaju also had the opportunity 
to be taught and strongly inspired by celebrated pioneers of African historical scholarship like Professors Kenneth Dike, Allan Ryder, and John D. Omer-Cooper, among others. These exposures awoke the needed drive and force that were the necessary recipes for a balanced successful career. Professional grounding in the humanities, specialization in historical science, and knowledge derived from elective courses gave uniqueness and edge to his academic career that followed.

His specialization area within History was African regional courses with particular interest in the West-African sub region, which is not shocking considering his origin as a cross-border citizen of Yorubaland. There began his interest in inter-colonial Anglo-French Nigeria-Dahomey (now Benin). In line with this, in his final year, he took special subjects in "Yorubaland and Dahomey in the $19^{\text {th }}$ century" as if in preparation for his life-long career in African comparative history and borderland studies. The course exposed him to firsthand primary sources of information on early Christian missionaries, European explorers, and the European partition of Africa, especially the Anglo-French division of his homeland.

The required courses from French studies also empowered Așiwaju, with the ability to communicate with "kith" and "kin" across the border in the then Republic of Dahomey and in the long run facilitated access to French colonial archives and other necessary information when he made the choice to embark on pioneer local studies of the impacts of French and British colonialism in West Africa. Așiwaju's doctoral research topic, upon advancing up the academic ladder after his first degree, solidified the basis of his career in comparative borderland studies. His thesis was framed as "The Impact of French and British Administrations on Western Yorubaland, 1889-1945”. It was the first research in the subfield of comparative history in the department. Thus, several challenges arose, such as that of comparing two social systems rather than the conventional focus on a single system, the challenge to provide balanced knowledge on both sides, and data collection, to mention a few. The special subject from the final year and courses from French studies came to his rescue. He went to the necessary places on both sides of the border for data collection.

The research topic evidently links with Așiwaju's origin, thus affirming the earlier position that his life and work are intertwined. Although formal research work had been for the doctoral degree, the interest had been there intrinsically with his birth and origin in an African border region. Ketu was partitioned by the Anglo-French colonial boundary in the $19^{\text {th }}$ century, which made Imeko fall on the other British-Nigeria side. The nature of this origin in an international border area already exposed him to firsthand background knowledge about borderlands and systems. Stories from his grandparents 
about victims of the war between Dahomey and western Yoruba states and also slavery, for instance, inspired his B.A. project on "Yorubaland and Dahomey in the $19^{\text {th }}$ century". Thus, he was motivated to discern the in-depth impact of the British and French colonial administrations on his homelands in West Africa. Originality was characteristically present in his work and, hence, its breakthrough. Above all odds and delays, his doctoral dissertation was successfully defended on 18 June 1971. Bridging Boundaries explicitly unravelled how he tackled the challenges and the complexities involved in the research. The acceptance and appreciation of the pioneer research from readers within and outside Africa prompted the revision of the thesis and its publication in 1976 as Western Yorubaland Under European Rule, 1889-1945: A Comparative Analysis of French and British Colonialism.

The numerous reviews, follow-up studies, and increasing awareness brought about the decision to embark on an Africa-wide research project focusing on the subject, "Partitioned Africans". The research took Așiwaju to many African countries and exposed him to sample cross-border areas in all the five sub-regions of the continent. The resultant publication, Partitioned Africans: Ethnic Relations Across Africa's International Boundaries, 18841984, was concurrently published in Africa, Europe, and North America in $1984 / 1985$, which marked a major achievement in research and also served as an eye-opener to the opportunities of expansion, if harnessed, into the global realm that lay before him.

The theoretical restructuring from studies of colonial administrative impacts to an emphasis on borderland studies set in with the intercontinental expansion of Așiwaju's scope. The rims began to expand, the radius widen. His sabbatical leave in 1982/83 was spent partly to complete the manuscript of Partitioned Africans and to delve into the global comparison of Borderlands studies. It was as part of this goal that he examined the US side of the US/ Mexico borderlands. His horizon carried knowledge from Africa to the West. He collaborated with leading experts and scholars in American Borderland Studies at the Center for Inter-American and Border Studies (CIABS) of the University of Texas at El Paso, which houses most of the scholars of US/Mexico border studies. He was able to appreciate the similarities between border studies elsewhere and that of Africa. A conference hosted by CIABS themed "Cross-border interactions in comparative perspectives with case studies of Europe, Africa, Latin America, and North America" exposed him to interactions with European border study scholars and opened his mind to the possibility of comapring European and African border studies as well. Importantly, expansion into European comparative borderland studies revealed substantial similarities between the two. Unlike North America, which only has borders between the U.S., Canada and Mexico, Europe has more boundaries like 
Africa. As a result of the similarities and complexities of both sides, comparative European borderland studies helped him deepen African knowledge, while projecting ideas that have benefited Europe that can benefit Africa as well as in borderland interactions and cooperation.

Partitioned Africans opened the door to more places, as in a special invitation Așiwaju received concurrently as visiting Professor of History and first Senior Scholar on border-focused Program of International Cooperation in Africa (PICA) at the Northwestern University in 1989-1990, followed by participation in a three-year research project on the security of marginal populations sponsored by the Committee on International Peace and Security of the US Social Science Research Council through a grant from the John D. and Catherine MacArthur Foundation. The research took him to many places in the U.S. His reputation paved the way to membership and involvement in the Association of Borderland Studies (ABS), eventually getting him elected to its Governing Council. He was also the first African scholar to be enrolled in the membership of the African Borderlands Research Network (ABORNE) created in 2007.

\section{Importance and Impacts of Comparative Borderland Studies}

Bridging Boundaries, in addition to a detailed education about the history of his career, fundamentally enlightens us on the impact and social application of borderland studies. It serves as a guide to students and scholars in the field in seeing various ways to build on his achievements to move us forward. It is also useful for professionals outside the field as it extensively gives account of the importance and usefulness of the multidisciplinary collaborations he has developed with scholars in such fields as geography and political science.

Above personal academic and professional achievements, Professor Așiwaju has used comparative borderland studies to touch upon numerous academic and policy issues. Bridging Boundaries successfully promoted the need for policy formulation and implementation. His research is extremely valuable to borderland policy agencies.

With regard to policies, Professor Așiwaju broke down the lines between the universities and governance. For instance, his inaugural lecture presented in 1984, titled "Artificial Boundaries," was well received by the public and earned him an invitation by the then head of state, General Muhammad Buhari, during his military regime, to join and help guide a border security and defence research project domiciled at the National Institute for Policy and Strategic Studies (NIPSS), Kuru, Jos. This invitation was based on the premise that academic research is useful to a policy-oriented project on "A detailed ethnographic survey of Nigeria's border and cross-border localities and 
communities". This invitation was an immense opportunity to actually direct his research ideas into a serious policy-making arena. As an achievement, it led to the creation of the National Boundary Commission by Decree 38 of 17 December 1987 and his appointment as the foundation commissioner with a full-time official responsibility of taking charge of the nation's international boundaries by May 1988. The commission was able to plan and develop interconnected border regions and the fostering of peaceful delimitations and demarcations of the borders within Nigeria.

In addition, as the foundation commissioner at the national level, Așiwaju was able to channel the commission's developmental projects into the border areas of Ogun state. These projects included building a model primary school and rural hospital with an ambulance. A veterinary clinic for the locally settled cattle Fulani community was also created as well as stalls for a modern border market. In addition, he has rendered numerous services to regional organizations such as his stellar contribution to the formation of the Economic Community of West African States (ECOWAS), Cross-Border Initiatives Programme (CIP) in 2005, and the African Union Border Programmes (AUBP), all geared towards integration among African countries.

With full knowledge of social circumscription, the ambits of Așiwaju's reach kept expanding. His reputation as someone interested in the localized impacts of European colonization, borders, boundaries, peace, and conflict resolution also earned him appointment as State Boundary Commissioner in Ogun State between 2003 and 2011 during the tenure of Governor Gbenga Daniel. He was able to keep boundary peace and understanding with neighboring states like Oyo, Lagos, and Osun. Able to handle the art of brinkmanship, he prevented conflicts at several points in time in three states over unauthorized timber felling in forest reserves. He organized a workshop that birthed bilateral agreements between Nigeria and Benin, fostering improved relations between traditional rulers through strengthened traditional practices.

Professor Așiwaju's pale of expertise as the country's preeminent borderland scholar helped him to achieve border security enhancement, conflict management and prevention, cross-boundary cooperation, policy promotion, and border region developments. Thus, he channelled his knowledge from borderland studies into taking practical measures concerned with the betterment of society with special attention to marginalized rural areas.

This piece is both about Așiwaju and his book, both within the same perimeter of the knowledge on boundaries. The man operates in the margins of places and spaces, and the book moves his achievements to the centre of a significant intellectual universe. A bricklayer in the boundary layers of Imeko, 
he was bound by Western education to cross boundary lines; and his outstanding scholarship catapulted him to boundary peaks.

Bridging Boundaries is an invaluable book without boundaries: its significance cannot be branded and bounded in just the discipline of History; its contents will elevate the boundaries between the academy and government; and its readers will be within and outside the territories of Nigeria as the umbrella of this pathfinder's career knows no frontiers, unbounded by lines. The emeritus professor projects unity and similarities in the complexities of various continents, his farthest limits of knowledge reach out to the compass of global integration and collaboration, detouring to cross-border relations, averting cross-border conflicts, and fostering growth individually, intra-continentally, and collectively intercontinentally.

The intellectual environs of Bridging Boundaries will appeal to students. Its abuttals feed the needs of scholars. Its precincts will motivate professionals who seek solutions to conflicts. Its terminus will supply ideas on the importance of border and boundary-related studies, a subfield that he pioneered under the wider comparative historical studies framework. The mere that he foregrounds invites us to own the book, as it strategically draws attention and interest to conventionally marginalized borderlands in order to enhance their developments. The end of knowledge, if there is any end, appeals for purposeful and productive cross-border unity and cooperation in order to reduce and subsequently prevent intra and inter-territorial hazards that may arise from conflicts.

Because of the intrinsic auto-suggestive controlling and self-fulfilling prophetic powers in the names we bear-orúkọ n' roni, ìnágíjẹ n' roni-Yoruba are most thoughtful in choosing the names for their children. Așiwaju-the man who leads, as his family name defines both his character and achievementshas clearly offered us strategic road map, compass and demarcation lines that clamour for a deeper African integration process starting with Nigeria, his motherland, and then to the limitrophe proximities in West Africa and other regions in Africa, his fatherland, and finally globalizing the integration and unity of the world-his diasporaland-as boundaries and borderlands are everywhere across the globe, all for one singular motive: the development and peaceful existence of the human race.

May he continue to live long to lead, as his Așiwaju title-like name stamps this destiny on him. As I rename Anthony to Ifátonì, I bless him with Odù Òtúá Méji:

Ònàkántihínwá,

Ờnàkántọhúnwá;

İpàdéọnàméji

Abẹnuṣonșo. 
(One path comes from here/within, Another comes from there/yonder;

The meeting point:

Crossroad of two pathways that

Produces a pointed/sharp edge.)

This odù denotes the power of togetherness and unity culminating into a fusion of power (àsę), an endless flow and radiation of human energy manifested in and from the scholar who relentlessly pursues the frontiers and the paths that lead to them. 